DANIJELA PJEVČEVIĆ, M.Sc.

Email: danijela@sf.bg.ac.rs

ALEKSANDAR RADONJIĆ, M.Sc.

Review

Email: a.radonjic@sf.bg.ac.rs

ZLATKO HRLE, Ph.D.

Email: hrle@sf.bg.ac.rs

VLADETA ČOLIĆ, Ph.D.

Email:v.colic@sf.bg.ac.rs

University of Belgrade,

Faculty of Transport and Traffic Engineering

Vojvode Stepe 305, 11000 Belgrade, Serbia
Accepted: Nov. 10, 2010

Approved: Dec. 20, 2011

\title{
DEA WINDOW ANALYSIS FOR MEASURING PORT EFFICIENCIES IN SERBIA
}

\begin{abstract}
The aim of the paper is to apply Data Envelopment Analysis (DEA) method in measuring and analyzing the efficiencies of ports on the Danube river. DEA window analysis is used to determine the efficiency of ports and to observe the possibility of changes in the port efficiency over time. A study is conducted to evaluate the efficiencies of ports on the territory of Serbia in order to identify the sources of inefficiencies and formulate proposals for improving the services of those ports and their operations through a four-year window analysis with port efficiency trends and average efficiencies. The progress is made in the measurement of port efficiency in relation to port productive activities - total area of warehouses, quay length, number of cranes and port throughput, for the Serbian river ports.
\end{abstract}

\section{KEYWORDS}

river ports, total area of warehouses, quay length, number of cranes, port throughput, port efficiency, DEA window analysis

\section{INTRODUCTION}

River port is the crucial point where goods are transferred between river ships and road vehicles and trains. Because of this fact, the significance of river port and its production cannot be ignored. In Serbia river ports are located away from the coastal borders of neighbouring countries facilitating the process of international trade through multimodal transport chains. As an interface, port offers the opportunity for satisfying the standard services (transferring cargo to or from land) through port operations as well as some additional services (distribution, depot, repair...).

Standard services are performed with cargo handling terminals within the ports compiling operational information for all port services. In order to increase the competitiveness of the terminals the port authorities have to invest in port capacity and at the end of each period of time (year end) they must demonstrate the justifiability of investments. The investments in port and traffic infrastructure prove their justification in upgrading the level of terminal quality and capacity as well as in increasing incomes that can be generated by implementing the development plans for the modernization of the port [11]. Therefore, the management of a terminal or port authorities must develop an appropriate decision-support model, in order to make an adequate support to strategic decisions [22]. The contribution of the Serbian river ports to the economic system and the economic development of the country is undeniable. Therefore, the port production and the port performance measurement have always had major impact in the economic growth of the country. It is important to analyze the efficiency of port activities and to search tools to improve the service of these ports. One of the most important ways to measure port performance is the efficiency of port and one of the most important approaches to measuring port efficiency is the method of DEA.

With the purpose of planning dry bulk cargo handling, Pjevčević and Vukadinović [17] analyzed the river port terminal capacity and gave proposals for capacity increase. Three different scenarios have been proposed and each scenario demanded involvement of certain labour force, and the main and auxiliary loading/unloading equipment. The simulation models of the proposed scenarios have been developed with the purpose of analyzing performance measures of cargo handling and examining their influence on the terminal capacity. Besides the simulation results analysis, the analysis of efficiency of proposed scenarios of 
cargo handling using Data Envelopment Analysis (DEA) method has been done. The DEA method gave the possibility of observing and analysing the efficiency of the proposed scenarios and their sub-scenarios of dry bulk cargo handling.

The measurement of port efficiency has gone in the direction that connects it with port productive activities. A significant progress has been made concerning the measurement of port efficiency in relation to port productive activities. Marlow and Paixão (2002) [15] suggested the DEA method for port performance measurement. Several applications of DEA have been used for the sea port industry by Tongzon (2001) [21] Valentine and Gray [23] (2001) and Martinez-Budria [14] (1999). The proposed applications are limited to the standard DEA models such as the CCR (Charnes, Cooper and Rhodes, 1978) [3].

Reviewing the literature, the authors mainly found studies dealing with seaport efficiencies where most of the ports belong to Southwest Europe, Asia, Australia and North America. The papers mainly include 20 or more seaports and terminals per research which represents a solid number of data and various results in evaluating port efficiency.

In this paper an analysis of the annual panel data for the years 2001-2008 from five river ports (Prahovo, Smederevo, Belgrade, Novi Sad and Pančevo) in Serbia has been performed for estimating the port efficiency. The efficiency of the proposed Serbian ports has been evaluated over time by applying the DEA window analysis.

Lack of data availability and the small sample size (just five ports) denied authors to get better impact of inputs on the port performance. For example, the port of Prahovo throughput is zero and can be therefore disqualified automatically for the year 2003. This serious deficiency can be overcome by further data collecting.

The objective of the paper is to evaluate the efficiencies of ports in order to identify the sources of inefficiencies and to make the proposals for the future planning and improvement of port operations.

The results show the variability in the port efficiency. The Window analysis indicates that all ports have inefficiencies during some periods of time. Therefore, it is necessary to examine the strategic plan for improving the port operations, improving the port performance and making better use of the capacities in ports.

\section{LITERATURE REVIEW}

By analyzing the port production using the DEA method it is possible to take into consideration multiple inputs and multiple outputs.

During the last two or three decades many research papers attempting to evaluate the port efficiency using the DEA method have been conducted. The research papers can be roughly divided into two groups according to the data analyzed. The first group represents studies analyzing cross-sectional data, while the second group deals with panel data. Both groups of papers compare the efficiency of ports in the European countries, the Asian countries [13] (Lee, Kuo and Chou, 2005), the USA and Australia [8] (Cullinane et al., 2005). However, as far as the authors know, research works have not included ports of the Danube region. In the recent years the DEA method has successfully applied to the analysis of container terminal in seaports.

Roll and Hayuth [19] (1993) applied the DEA technique in their studies on the port sector. They recommended cross-section data in assessing the relative effectiveness of various ways of organizing port services. Although they introduced multiple outputs such as port throughput and customer satisfaction their work was restricted to the application of the standard DEA methods such as the DEA-CCR model. In addition, their work was limited to the one period of time. They examined 20 seaports and chose the size of the labour force, annual investment per port and the uniformity of facilities and cargo as input variables and the number of containers, the level of service, customer satisfaction and the number of ship calls as output variables.

Martinez-Budria [14] et al. (1999) made three groups from 26 Spanish ports: 'high complexity ports', 'medium complexity ports' and 'low complexity ports'. They examined the efficiency of ports using the DEACCR and DEA-BCC (Banker, Charnes, and Cooper, 1984) models and concluded that high complexity ports were associated with high efficiency, compared with the random mix of medium and low efficiency found in the other two types of ports. In the model of 26 ports the input units included labour expenditures, depreciation charges and miscellaneous expenditures, while output units included the total cargo moved through the docks and revenue from the port facilities.

Tongzon [21] (2001) analyzed the efficiency of four Australian and twelve international seaports for the year 1996. He made a conclusion that all seaports were the most inefficient mainly due to the extent of slack in the inputs. His inputs were the number of cranes, the number of container berths, the number of tugs, terminal area and delay time. The outputs included cargo throughput and ship work rate.

Valentine and Gray [23] (2002) compared the efficiency of 31 North American and European ports for the year 1998 forming outputs such as containers as total throughput and the number of containers and inputs, such as the total length of berth and container berth length. According to these authors the DEA method is useful to test the container seaport efficiency.

Barros [1] (2003) analyzed technical and allocative efficiency of five Portuguese ports from 1999 to 2000 using cross-section data. The main objective was to 
investigate how port regulatory procedures affect the productivity of the port. He concluded that the incentive regulation for increasing productive efficiency was not achieving its aims and proposed a policy revision to enforce efficiency. For inputs he took the number of employees and the book value of assets and for outputs he took ships, movement of freight, gross tonnage, market share, break-bulk, liquid bulk, containers, Ro-Ro etc.

The same author [2] with Athanassiou (2004) studied the relative efficiency of Portuguese and Greek ports using the DEA method. The results of the analysis indicated that there were inefficiency ports which could improve their performance. Also, privatization of ports was proposed as the most appropriate method for achieving the economic efficiency.

Cullinane et al. [7] (2004) in their study evaluated the efficiency score of the world's major container seaports over time with the DEA window analysis using panel data and cross-section data. They compared the cross-section method and the panel data with the window analysis concluding that the cross-section method did not yield port performance in detail. The panel data with the window analysis demonstrated a variation of the absolute performance of a port over time, and the relative performance of that port in comparison to the others at the same time.

Min and Park [16] (2005) used the DEA window analysis to evaluate the efficiency of 11 container terminals in a period of four years. The applied DEA window analysis enables observation of the changes in terminal efficiencies over time. The data included the total quay length, the number of cranes, labour number, size of storage, all belonging to inputs and cargo throughput as the output.

Cullinane and Wang [9] (2006) studied the efficiency of 69 container terminals with an annual throughput of over 10,000 TEUs in Europe using crosssectional DEA. They pointed to the existence of the significant inefficiency for the most of the terminals. It has also been evidenced that the average efficiency of container terminals located in different regions differs, either to a large or to a small extent. The inputs were the terminal length, size of terminal area, equipment (expressed in numerical value), while container throughput was the output. The same authors [24] (2002) examined the applicability of the DEA method to container port efficiency measurement.

Kaisar, Pathomsiri and Haghani [12] (2006) analyzed the port productivity using the DEA method. They determined an efficient frontier or a set of the best practice ports, which inefficient ports may want to emulate and then concentrated on the sources and the extent of inefficiency of ports which could improve their operations. Assuming that the container port depends on the equipment and information technology and by the competition among ports, the main objective of their study was to minimize the use of inputs (the total quay length and the quay gantry cranes) and to maximize the output (container throughput). The annual panel data from 1998 to 2003 have been collected for each of twenty-five ports.

\section{DEA ANALYSIS}

DEA is a nonparametric method of measuring the efficiency of a decision-making unit (DMU) such as a firm or a public-sector agency [20], first introduced into the Operations Research (OR) literature by Charnes, Cooper, and Rhodes (CCR).

The decision-making units (DMUs) can be different organizations, departments or groups, all with the similar functions, goals and market segments. DEA is designed to identify the best practice DMU without a priori knowledge of which inputs and outputs are most important in determining an efficiency measure (i.e. score) and assess the extent of inefficiency for all other DMUs that are not regarded as the best practice DMUs [3].

With DEA as a nonparametric method, it is not possible to obtain the conclusions about the technology, which can be derived from a parametric method. It is not possible to provide a general equation relating to input and output.

Being non-statistical in nature, the LP solution of a DEA problem produces no standard errors and leaves no room for hypothesis testing. In DEA, any deviation from the frontier is treated as inefficiency and there is no provision for random shocks [20].

The DEA model (M1) is mathematically expressed as $[5,6]$ :

$$
(M 1)\left\{\begin{array}{l}
\operatorname{Max} h_{k}(u, v)=\frac{\sum_{r=1}^{s} u_{r} y_{r k}}{\sum_{i=1}^{m} v_{i} x_{i k}} \text { for all } k=1,2, \ldots, n \\
\text { subject to } \\
\sum_{r=1}^{s} u_{r} y_{r j} \\
\sum_{i=1}^{m} v_{i} x_{i j} \\
u_{r} \geq 0, \quad r=1, \quad j=1,2, \ldots, n \\
u_{i} \geq 0, \quad i=1,2, \ldots, m
\end{array}\right.
$$

where:

$h_{k}$ is relative efficiency of $k$-th DMU, $y_{r j}$ is amount of output $r$ produced by DMU $j, x_{i j}$ is amount of input $i$ used by DMU $j, n$ is the number of DMUs, $m$ is the number of inputs, $s$ is the number of outputs, $u_{r}$ is the weight given to output $r$ and $u_{i}$ is the weight given to input $i$.

The above model (M1) is solved $n$ times to evaluate the relative efficiency of each DMU. Mathematically, the nonnegative constraints (3) and (4) are not sufficient for the fractional (2) to have a positive value. Due 
to that it is assumed that all weights for inputs and outputs assign some nonzero value.

Since the efficiency of $k$-th DMU is maximized by solving the expressions (1), (2), (3) and (4) it is obvious that $h_{k}$ will take values from 0 to 1 . If the value for $h_{k}$ is equal to 1 , then the $k$-th DMU will be efficient relative to other DMUs; otherwise, the value of $h_{k}$ indicates the inefficiency of $k$-th DMU. The inefficiency of some DMU can be treated as "less efficient DMU" if the value of $h_{k}$ is close to 1 .

This problem is defined as the fractional linear programming model (M1), known as "CCR ratio model", which can be reduced, using transformations, to the linear programming model (M2). The DEA model (M2) is formulated in the following form:

$$
\text { (M2) }\left\{\begin{array}{l}
\operatorname{Max} h_{k}(\mu, v)=\sum_{r=1}^{s} \mu_{r} y_{r k} \text { for all } k=1,2, \ldots, n \\
\text { subject to } \\
\sum_{i=1}^{m} v_{i} x_{i k}=1 \\
\sum_{r=1}^{s} \mu_{r} y_{r j}-\sum_{i=1}^{m} v_{i} x_{i j} \leq 0, \quad j=1,2, \ldots, n \\
\mu_{r} \geq \varepsilon, \quad r=1,2, \ldots, s \\
v_{i} \geq \varepsilon, \quad i=1,2, \ldots, m
\end{array}\right.
$$

where:

$h_{k}$ - relative efficiency of $k$-th DMU;

$n$ - number of DMUs that should be compared;

$m$ - number of input values;

$s$ - number of output values;

$\mu_{r}$ - weight of the output value $r$;

$v_{i}$ - weight of the input value $i$.

If the value of $h_{k}$ in the objective function is equal to 1 , then $k$-th DMU is relatively efficient. However, if it is less than 1 , then $\mathrm{DMU}_{\mathrm{k}}$ is relatively inefficient and the value of $h_{k}$ shows the percentage by which DMU should decrease its inputs. $\mathrm{DMU}_{\mathrm{k}}$ can be considered fully efficient only, and only if, the values of other DMUs do not provide the evidence that any of its inputs or outputs could be improved without impairing any other input or output.

Looking at expressions (5), (6), (7), (8) and (9) (in model M2) it is obvious that time as a component is not incorporated.

So, we can consider solutions at a particular point in time, or we can just analyze data through time series. If we ignore time or compare the performance of a number of DMUs at one period of time we will use cross-sectional analysis. But omitting the other time periods may lead to excessive use of resources and deficiencies in the production in future periods. In contrast to cross-sectional analysis we can perform a time series analysis, which in practice means that DMUs are observed over multiple time periods. The variations of efficiency of DMUs over time can help in making important conclusions [18].
One way of using the DEA method in time series mode is the DEA Window Analysis. This mode is described in Charnes et al. [4]. A DMU in each period is a different DMU and the data for use in the analysis is panel data. The performance of a DMU is compared with its performance in other periods of time and with other DMUs in the same period of time. For instance, if $n$ DMUs in model (M2) in N periods of time are considered, then a total of nxN DMUs need to be assessed simultaneously since DMU in year 1 is treated as a different DMU as compared to the same DMU in year 2 .

In many practical applications the available data for the DEA efficiency evaluation are from different time periods (for example, data can be monthly, quarterly, yearly, etc.). If we need to estimate the efficiency of $n$ units that have collected data on their input/ output levels at any of $\mathrm{N}$-time periods, it is possible to gather input/output levels during one selected period and make only one assessment of $\mathrm{n}$ units. However, this does not get information about how the efficiency of individual units may vary over time. Changes in efficiency may be due to changes in personnel and/or operational policy or as a result of seasonal factors that are in different units dependent on a variety of ways. The DEA method can be used for monitoring the efficiency of $\mathrm{N}$ time periods and in two ways:

- in the first way each unit in each time period is considered as a different unit for evaluation, which means that we should evaluate the total of $n \times N$ units;

- another way is to track efficiency over time by applying the window analysis. The window analysis consists of choosing the window length $p$ and then evaluating $n \times p$ efficiencies for each window (the number of windows depends on the time span considered). One who performs the analysis has to determine the length of the window. An important advantage of the window analysis is that it effectively increases the number of units for evaluation, which in turn increases the discriminatory power of the method.

\section{ANALYZING THE EFFICIENCY OF PORTS WITH PANEL DATA}

The paper analyzes the efficiency of five ports in Serbia: Prahovo, Smederevo, Belgrade, Novi Sad and Pančevo. Since all five ports are in Serbia the fair comparison between ports is achieved through the same status in the country, same economic conditions, same rules and policies. The efficiency analysis of proposed ports is performed using the DEA window analysis. The data include the total area of warehouses, quay length, number of cranes and port throughput per year all collected over an 8-year period from 2001 to 2008. The efficiencies of ports are compared over a 
D. Pjevčević, A. Radonjić, Z. Hrle, V. Čolić: DEA Window Analysis for Measuring Port Efficiencies in Serbia

Table 1 - Cargo throughput (in thousands of tonnes) for the period from 2001 to 2008

\begin{tabular}{|c|c|c|c|c|c|c|c|c|}
\hline Ports & 2001 & 2002 & 2003 & 2004 & $2005 *$ & 2006 & 2007 & 2008 \\
\hline Prahovo & 224.6 & 224.6 & 0.0 & 237.0 & 54.0 & 332.0 & 389.6 & 299.5 \\
\hline Smederevo & 967.6 & $1,093.3$ & $1,622.0$ & 1,993.0 & $2,553.0$ & $2,607.0$ & $2,923.5$ & $3,030.4$ \\
\hline Belgrade & 245.8 & $1,396.0$ & 251.0 & 558.0 & $2,988.0$ & $2,474.0$ & $2,123.4$ & $2,541.9$ \\
\hline Novi Sad & 386.0 & 859.0 & 529.0 & 832.0 & 870.0 & $1,007.0$ & $1,275.2$ & 890.7 \\
\hline Pančevo & $1,480.3$ & $1,269.0$ & $1,331.0$ & $1,295.0$ & $1,469.0$ & $1,455.0$ & $1,788.9$ & $1,316.7$ \\
\hline
\end{tabular}

Source: Danube Commission [26], Statistical Office of the Republic of Serbia [27]

* Since $1^{\text {st }}$ January Statistical Office of the Republic of Serbia has announced changes in their methodology for statistical research

period of 8 years in addition to comparing them in the same period of time.

Table 1 provides an overview of the cargo throughput (in thousands of tons) in the above mentioned ports for the period from 2001 to 2008.

Graphic representation of changes in port throughputs per years is shown in Figure 1.

From Figure 1 it can be concluded that all ports registered throughput oscillations except for the port of Smederevo where throughput has been increasing constantly. The transport on inland waterways includes about $4.7 \%$ of the total transport carried out in Serbia, and the best throughput comes from the port of Smederevo, port of Belgrade and port of Pančevo. As can be seen in Table 1 the total cargo throughput for the port of Prahovo in 2003 stands at 0, making it the only port without transfer of cargo in 2003. That is why the idea of this paper is to investigate the port efficiency through window analysis.

The evaluation of port efficiency using the DEA method begins by choosing appropriate input and output variables. The total area of warehouses, quay length and number of cranes are chosen to be input variables while port throughput per year is declared as the output variable. One Decision Making Unit (DMU) corresponds to one port. The overview of input and output variables per ports and years is given in Table 2.
The Area of warehouses is dedicated to the warehouse operations of receiving, putting away, storing, retrieving, order picking, packing and shipping. The area of supporting activities, such as office, is not included. Also, covered storages and open storages are included, while racks, hazardous materials and free port zone, for example, are not included. The total area determines the amount of cargo that could transfer and store within port area in the case of no direct ship-to-ship loading or transferring cargo out of the port area on rail/road vehicles.

In the process of evaluating efficiency of the port one of the most important inputs is the quay length. Yen-Chun Jim Wu and Mark Goh [28] suggest that quay length is crucial to the efficiency of Chinese ports. In general, quay length differs from port to port on inland waterways. River ports are smaller than seaports and the quay length corresponds to the size of the ships that operate on the river. Since the shipping company main aim is to reduce the sum of the ships turnaround time, the optimum assignment of arrived ships to ports quay length becomes important strategy, while ports, competing for the clients (shipping companies) increase their efficiency.

The number of cranes directly influences the increase in port capacity and is therefore included in the input variables. More cranes bring increased efficiency

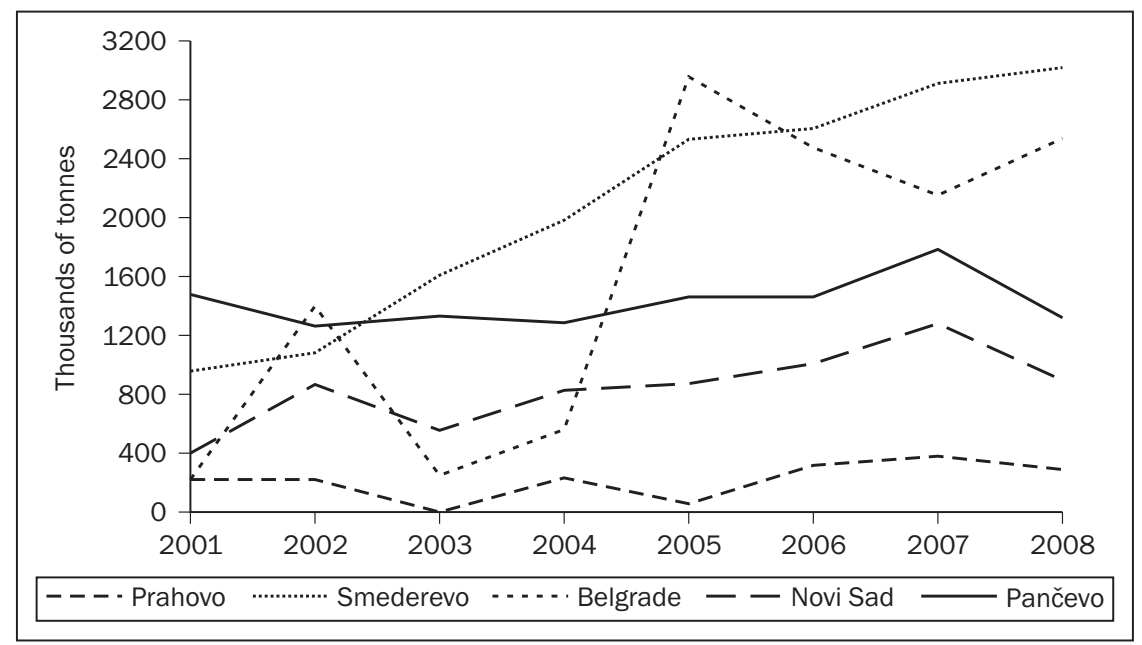

Figure 1 - Cargo throughput (in thousands of tonnes) for the 2001-2008 period 
and flexibility allowing port to work with more vessels simultaneously. Since the port facilities are very expensive, it is desirable to optimize their performance, making better management decisions. In particular, heuristics for port operations and functional and process modelling are used for scheduling loading/

Table 2 - Input and output variables

\begin{tabular}{|c|c|c|c|c|c|}
\hline Ports & Year & $\begin{array}{l}\text { Port throughput } \\
\text { (in thousands of tons) }\end{array}$ & $\begin{array}{c}\text { Total area of } \\
\text { warehouses } \\
\text { (in square metres) }\end{array}$ & $\begin{array}{l}\text { Quay length } \\
\text { (in metres) }\end{array}$ & $\begin{array}{c}\text { Number of } \\
\text { cranes }\end{array}$ \\
\hline \multirow{8}{*}{ Prahovo } & 2001 & 224.6 & 4,000 & 560 & 6 \\
\hline & 2002 & 224.6 & 4,000 & 560 & 6 \\
\hline & 2003 & 0 & 4,000 & 560 & 6 \\
\hline & 2004 & 237 & 4,000 & 560 & 6 \\
\hline & 2005 & 54 & 4,000 & 560 & 6 \\
\hline & 2006 & 332 & 4,000 & 560 & 6 \\
\hline & 2007 & 389.6 & 4,000 & 560 & 6 \\
\hline & 2008 & 299.5 & 4,000 & 560 & 6 \\
\hline \multirow{8}{*}{ Smederevo } & 2001 & 967.6 & 2,700 & 500 & 7 \\
\hline & 2002 & $1,093.3$ & 2,700 & 500 & 7 \\
\hline & 2003 & 1,622 & 2,700 & 500 & 7 \\
\hline & 2004 & 1,993 & 2,700 & 500 & 7 \\
\hline & 2005 & 2,553 & 2,700 & 500 & 7 \\
\hline & 2006 & 2,607 & 2,700 & 500 & 7 \\
\hline & 2007 & $2,923.5$ & 2,700 & 500 & 7 \\
\hline & 2008 & $3,030.4$ & 2,700 & 500 & 7 \\
\hline \multirow{8}{*}{ Belgrade } & 2001 & 245.8 & 950,000 & 950 & 16 \\
\hline & 2002 & 1,396 & 950,000 & 950 & 16 \\
\hline & 2003 & 251 & 950,000 & 950 & 16 \\
\hline & 2004 & 558 & 950,000 & 950 & 16 \\
\hline & 2005 & 2,988 & 950,000 & 950 & 16 \\
\hline & 2006 & 2,474 & 950,000 & 950 & 16 \\
\hline & 2007 & $2,123.4$ & 950,000 & 950 & 16 \\
\hline & 2008 & $2,541.9$ & 950,000 & 950 & 16 \\
\hline \multirow{8}{*}{ Novi Sad } & 2001 & 386 & 85,000 & 800 & 4 \\
\hline & 2002 & 859 & 85,000 & 800 & 4 \\
\hline & 2003 & 529 & 85,000 & 800 & 4 \\
\hline & 2004 & 832 & 85,000 & 800 & 4 \\
\hline & 2005 & 870 & 85,000 & 800 & 4 \\
\hline & 2006 & 1,007 & 85,000 & 760 & 4 \\
\hline & 2007 & $1,275.2$ & 85,000 & 720 & 5 \\
\hline & 2008 & 890.7 & 85,000 & 680 & 5 \\
\hline \multirow{8}{*}{ Pančevo } & 2001 & $1,480.3$ & 205,000 & 760 & 4 \\
\hline & 2002 & 1,269 & 205,000 & 760 & 4 \\
\hline & 2003 & 1,331 & 205,000 & 760 & 4 \\
\hline & 2004 & 1,295 & 205,000 & 760 & 4 \\
\hline & 2005 & 1,469 & 205,000 & 760 & 4 \\
\hline & 2006 & 1,455 & 205,000 & 760 & 4 \\
\hline & 2007 & $1,788.9$ & 205,000 & 760 & 5 \\
\hline & 2008 & 1,316.7 & 205,000 & 760 & 5 \\
\hline
\end{tabular}

Source: Via Donau [25], Danube Commission [26], Statistical Office of the Republic of Serbia [27] 
unloading operations by cranes in order to minimize the maximum time it takes to serve a given set of vessels [10]. As a result of that, overall time that vessels spend in the port is less, terminals are more available for other ships and the service offered to the port's customers is improving.

The total amount of cargo that is being transferred within the operational shore zone during the year can be measured by port throughput in total tons of cargo.

Specified input and output data are taken from the Statistical Yearbook of the Danube Commission (2001 - 2006), and from the Statistical Yearbook of the Republic of Serbia (2007-2008).

In order to monitor changes in the efficiency of the ports during the selected time period or "Window" DEA window analysis is used. The performance of five ports over an eight-year period of time is considered and then a four-year window is selected. There is no theory for the definition of window length. The experiments can be performed by selecting three, four or five-year window in order to determine the window length.
The first set of data includes analysis of port efficiency from the first four years. Analogously, the second set includes the data from the second, third, fourth and fifth year and after three shifting by one year the final fifth set includes data from the last four years. For each window a different set of data is made. Thus the result of various DMUs per four-year window leads to differences in port efficiency. This approach to efficiency analysis allows comparison of port efficiency over the eight-year time period. The results of window analysis are solved according to model M2 and arranged in Table 3.

Table 3 is a report of the results for the DEA window analysis. The length of the window is defined as four. Five windows are represented as five rows per one port. Each port is represented as a different DMU at each of the four successive years.

Owing to continuous low percentages (Table 3) it can be concluded that the port of Prahovo is the most inefficient one in five windows. Looking at the values for inputs and output of the port of Prahovo it is clear

Table 3 - DEA efficiencies of five ports for years 2001-2008 using a four-year window

\begin{tabular}{|c|c|c|c|c|c|c|c|c|c|}
\hline & 2001 & 2002 & 2003 & 2004 & 2005 & 2006 & 2007 & 2008 & Mean* \\
\hline \multirow{5}{*}{ Prahovo } & $13.13 \%$ & $13.13 \%$ & $0.00 \%$ & $13.85 \%$ & & & & & \multirow{5}{*}{$8.67 \%$} \\
\hline & & $10.26 \%$ & $0.00 \%$ & $10.83 \%$ & $2.47 \%$ & & & & \\
\hline & & & $0.00 \%$ & $10.61 \%$ & $2.42 \%$ & $14.86 \%$ & & & \\
\hline & & & & $9.46 \%$ & $2.15 \%$ & $13.25 \%$ & $15.55 \%$ & & \\
\hline & & & & & $2.08 \%$ & $12.78 \%$ & $15.00 \%$ & $11.53 \%$ & \\
\hline \multirow{5}{*}{ Smederevo } & $48.55 \%$ & $54.86 \%$ & $81.38 \%$ & $100.00 \%$ & & & & & \multirow{5}{*}{$80.86 \%$} \\
\hline & & $42.82 \%$ & $63.53 \%$ & $78.07 \%$ & $100.00 \%$ & & & & \\
\hline & & & $62.22 \%$ & $76.45 \%$ & $97.93 \%$ & $100.00 \%$ & & & \\
\hline & & & & $68.17 \%$ & $87.33 \%$ & $89.17 \%$ & $100.00 \%$ & & \\
\hline & & & & & $84.25 \%$ & $86.03 \%$ & $96.47 \%$ & $100.00 \%$ & \\
\hline \multirow{5}{*}{ Belgrade } & $6.49 \%$ & $36.87 \%$ & $6.63 \%$ & $14.74 \%$ & & & & & \multirow{5}{*}{$31.04 \%$} \\
\hline & & $28.78 \%$ & $5.17 \%$ & $11.50 \%$ & $61.60 \%$ & & & & \\
\hline & & & $5.07 \%$ & $11.27 \%$ & $60.32 \%$ & $49.95 \%$ & & & \\
\hline & & & & $10.05 \%$ & $53.79 \%$ & $44.54 \%$ & $38.23 \%$ & & \\
\hline & & & & & $51.89 \%$ & $42.97 \%$ & $36.88 \%$ & $44.15 \%$ & \\
\hline \multirow{5}{*}{ Novi Sad } & $30.18 \%$ & $67.17 \%$ & $41.36 \%$ & $65.06 \%$ & & & & & \multirow{5}{*}{$53.20 \%$} \\
\hline & & $58.71 \%$ & $36.16 \%$ & $56.87 \%$ & $59.47 \%$ & & & & \\
\hline & & & $35.51 \%$ & $55.85 \%$ & $58.40 \%$ & $67.60 \%$ & & & \\
\hline & & & & $49.80 \%$ & $52.08 \%$ & $60.28 \%$ & $61.06 \%$ & & \\
\hline & & & & & $50.24 \%$ & $58.15 \%$ & $58.91 \%$ & $41.15 \%$ & \\
\hline \multirow{5}{*}{ Pančevo } & $100.00 \%$ & $85.73 \%$ & $89.91 \%$ & $87.48 \%$ & & & & & \multirow{5}{*}{$87.57 \%$} \\
\hline & & $86.39 \%$ & $90.61 \%$ & $88.16 \%$ & $100.00 \%$ & & & & \\
\hline & & & $89.35 \%$ & $86.93 \%$ & $98.61 \%$ & $97.67 \%$ & & & \\
\hline & & & & $77.52 \%$ & $87.93 \%$ & $87.09 \%$ & $85.66 \%$ & & \\
\hline & & & & & $84.83 \%$ & $84.02 \%$ & $82.64 \%$ & $60.83 \%$ & \\
\hline
\end{tabular}

* mean efficiency is the arithmetic mean of all the data for selected port 
Table 4 - Average efficiencies

\begin{tabular}{||l|r|r|r|r|r|r|r|r|r||}
\hline \multicolumn{1}{|c|}{ Ports } & \multicolumn{1}{c|}{2001} & 2002 & 2003 & 2004 & 2005 & 2006 & 2007 & 2008 & Average \\
\hline \hline Prahovo & $13.13 \%$ & $11.69 \%$ & $0.00 \%$ & $11.19 \%$ & $2.28 \%$ & $13.63 \%$ & $15.27 \%$ & $11.53 \%$ & $9.84 \%$ \\
\hline Smederevo & $48.55 \%$ & $48.84 \%$ & $69.05 \%$ & $80.67 \%$ & $92.37 \%$ & $91.73 \%$ & $98.24 \%$ & $100.00 \%$ & $78.68 \%$ \\
\hline Belgrade & $6.49 \%$ & $32.82 \%$ & $5.62 \%$ & $11.89 \%$ & $56.90 \%$ & $45.82 \%$ & $37.55 \%$ & $44.15 \%$ & $30.16 \%$ \\
\hline Novi Sad & $30.18 \%$ & $62.94 \%$ & $37.68 \%$ & $56.89 \%$ & $55.05 \%$ & $62.01 \%$ & $59.99 \%$ & $41.15 \%$ & $50.74 \%$ \\
\hline Pančevo & $100.00 \%$ & $86.06 \%$ & $89.96 \%$ & $85.02 \%$ & $92.84 \%$ & $89.60 \%$ & $84.15 \%$ & $60.83 \%$ & $86.06 \%$ \\
\hline \hline
\end{tabular}

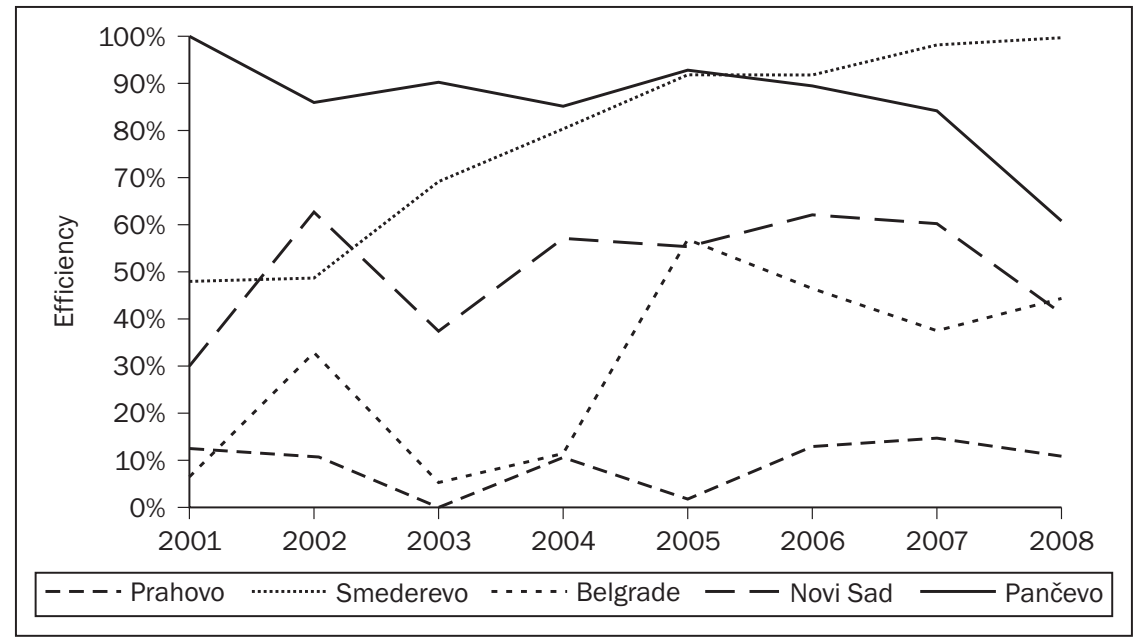

Figure 2 - Analysis of port efficiency trends

that there exists substantial waste in production. For example, the efficiency for 2003 is equal to 0 , as expected, since the port throughput is 0 tons for the same year. What has been told for the port of Pančevo is the opposite to what is read in Table 3 for the port of Smederevo. There is significant increase in the efficiency at the port of Smederevo over time as well as at a particular point in time reaching $100 \%$ at the end of the period in all windows. Thus the port of Smederevo becomes an efficient port. The port of Belgrade and Novi Sad have low operational efficiency and are considered inefficient. The area of warehouses, quay length and the number of cranes are poorly utilized in comparison with the achieved throughput in these ports. The port of Pančevo can be considered as an efficient port from 2001-2006 since its efficiencies through the first three windows never fall below 85\%. After 2006 there is an evident decline in efficiency caused by reduced throughput and simultaneous increase in one input - the number of cranes, from four to five cranes. The overall efficiency for the port of Pančevo is never below $60.83 \%$ indicating that there exists good answer to a specified output. The average efficiency is shown in Table 4 and the efficiency trend analysis in Figure 2.

Based on the analysis of the average efficiency (Table 4 and Figure 2) none of the studied ports has high efficiency equal to $100 \%$. The port of Pančevo can be separated as a port that has the highest value of average efficiency (86.06\%). The average efficiencies for the rest of the ports, and in particular for the port of Prahovo and the port of Belgrade, are lower than the average efficiency for the port of Pančevo. Their capacities are too excessive in relation to their throughputs. This means that it is necessary to attract customers or to increase the amount of cargo that can be transferred. The next solution is to reduce the use of considered inputs in proportion to the achieved output in these ports. Most of this reduction could be achieved by renting the port equipment to other companies. For example, the port of Belgrade should reduce its inputs by $69.84 \%$ in order to be efficient.

\section{CONCLUSION}

This study was performed in order to estimate the efficiency of five river ports on the Danube river in Serbia for the years 2001-2008 as well as to find the sources of their inefficiencies. The efficiencies of the Serbian river ports are determined over time by applying the DEA window analysis.

The data for use in the analysis are panel data. In an effort to get port efficiency over time and to get its stability over time the DEA method is combined with panel data in the window analysis model. The sources of potential inefficiencies are identified and analyzed. The proposals for future planning in ports and proposals for better use of capacities in ports are made on the basis of estimated efficiencies. The lack of data 
availability and the small sample size (just five ports) reveals that there is great impact of inputs on output.

The input data are composed of the total area of warehouses, quay length and number of cranes while output data include port throughput per year. The results reveal that the port of Pančevo efficiency was $100 \%$ in 2001 , while the port of Smederevo had $100 \%$ efficiency in 2008 and the other three ports efficiencies do not reach the maximum in neither of the 20012008 period of time. This suggests that the inputs for these two ports adequately respond to a given output for 2001 and 2008 (Table 4). However, the average efficiency in all ports is below $100 \%$. It means that all ports have more (port of Prahovo and port of Belgrade) or less (port of Pančevo) inefficiencies. There are two main sources of inefficiencies. First, the ports with low efficiencies are advised to attract more customers or to increase the amount of cargo that can be transferred. Second, the ports should rent their equipment to other companies in order to level the achieved output (throughput) with the use of inputs (total area of warehouses, quay length and number of cranes).

For all ports it is important to examine the strategic plan for improving the port operations, better use of capacities in ports and search tools to improve the service of these ports. Progress is made in the measurement of port efficiency in relation to port productive activities.

The lack of data availability affects the number of studied ports as well as the number of inputs and outputs and is likely to overshadow the real reasons behind the port efficiency. Thus, the research conducted here can be the beginning of one more complex analysis rather than an end of the same.

\section{Mr DANIJELA PJEVČEVIĆ \\ E-mail: danijela@sf.bg.ac.rs \\ Mr ALEKSANDAR RADONJIĆ \\ E-mail: a.radonjic@sf.bg.ac.rs \\ Dr ZLATKO HRLE \\ E-mail: hrle@sf.bg.ac.rs \\ Dr VLADETA ČOLIĆ \\ E-mail:v.colic@sf.bg.ac.rs \\ Univerzitet u Beogradu, Saobraćajni fakultet \\ Vojvode Stepe 305, 11000 Beograd, Srbija}

\section{REZIME}

\section{PRIMENA VREMENSKE ANALIZE OBAVIJANJA PODATAKA ZA MERENJE EFIKASNOTI LUKA U SRBIJI}

U radu je prikazana primena DEA metode (Analize obavijanja podataka) za merenje i analizu efikasnosti rečnih luka na Dunavu na teritoriji Srbije. Izvršena je analiza efikasnosti korišćenjem vremenske DEA metode koja pruža mogućnost sagledavanja promene efikasnosti posmatranih luka tokom vremena. U radu se proučava efikasnost recnih luka na teritoriji Srbije, kroz vremenske prozore duzine cetiri godine, sa prikazom trenda efikasnosti i srednjom merom efikasnosti luka, u nameri da se identifikuju izvori neefikasnosti i formulisu predlozi za poboljšanje poslovanja luka. Napredak je napravljen u pogledu Prikazano merenje efikasnosti luka $u$ odnosu na njihovu produktivnost predstavlja doprinos $u$ analizi luka u Srbiji.

\section{KLUUČNE REČI}

rečne luke, ukupna površina skladišta, dužina keja, broj dizalica, promet, efikasnost, vremenska DEA (Analiza obavijanja podataka)

\section{LITERATURE}

[1] Barros, C.P.: Measurement of Efficiency of Portuguese Seaport Authorities with DEA, International Journal of Transport Economics, Vol. 30, No. 3, 2003, pp. 335354

[2] Barros, C. and Athanassiou, M.: Efficiency in European Sea Ports with DEA: Evidence from Greece and Portugal, Maritime Economics \& Logistics, Vol. 6, No. 2, 2004, pp. 122-140

[3] Charnes, A., Cooper, W.W., Rhodes, E.:(1978) Measuring the Efficiency of Decision Making Units, European Journal of Operational Research, Vol. 2, No. 6, 1978, pp. 429-444

[4] Charnes, A., Clark, C.T., Cooper, W.W., Golany, B.: A developmental study of data envelopment analysis in measuring the efficiency of maintenance units in the U.S. Air Forces, Annals of Operations Research, Vol. 2, No. 1, 1984, pp. 95-112

[5] Cooper, W.W., Seiford, M.L., Tone, K.: Introduction to Data Envelopment Analysis and Its Uses, Springer, New York, 2005

[6] Cooper, W.W., Seiford, M.L., Zhu, J.: Handbook On Data Envelopment Analysis, Springer, New York, 2006

[7] Cullinane, K., Song, D-W., Ji, P., Wang, T-F.: An Application of DEA Windows Analysis to Container Port Production Efficiency, Review of Network Economics, Vol.3, No.2, June 2004, pp. 184-206

[8] Cullinane, K., Song, D-W., Ji, P., Wang, T-F.: The relationship between privatization and DEA estimates of efficiency in the container port industry, Journal of Economics and Business, Vol. 57, No. 5, 2005, pp 433462

[9] Cullinane, K., Wang, T-F.: The Efficiency of European container ports: across-sectional Data envelopment analysis, International Journal of Logistics: Research and Applications, Vol.9, No.1, 2006, pp 19-31

[10] Gudelj, A., Krčum M., Twrdy, E.: Models and Methods for Operations in Port Container Terminals, Promet Traffic\&Transportation, Scientific Journal on Traffic and Transportation Research, 2010, Vol. 22, pp. 43-52

[11] Hlača, B., Meyak, V., Papeš, S.: Impact of containerization development in the port of Rijeka on the Rijeka traffic route, Promet Traffic\&Transportation, Scientific Journal on Traffic and Transportation Research, 2008, Vol. 20, pp. 317-321

[12] Kaisar, I.E., Pathomsiri, S., Haghani, A.: Efficiency Measurement of US Ports Using Data Envelopment Analysis, National Urban Freight Conference, Long Beach California, February 2006 
[13] Lee, H-S., Chou, M-T., Kuo, S-G.: Evaluating port efficiency in Asia Pacific region with recursive data envelopment analysis, Journal of the Eastern Asia Society for Transportation Studies, Vol. 6, 2005, pp. 544-559

[14] Martinez-Budria, E., Diaz-Armas, R., Navarro-Ibanez, M., Ravelo-Mesa, T.: A study of the efficiency of Spanish port authorities using data envelopment analysis, International Journal of Transport Economics, Vol. 26, No. 2, 1999, pp.237-253

[15] Marlow, P. and Paixão, A.C. (2002), Measuring Lean Ports Performance, Proceedings of the International Association of Maritime Economists Conference, November, Panama, pp. 13-15

[16] Min, H., Park, B.I.: Evaluating the inter-temporal efficiency trends of international container terminals using data envelopment analysis, Int. J. Integrated Supply Management, Vol. 1, No. 3, 2005, pp 258-277

[17] Pjevčević, D., Vukadinović, K., Efficiency measurement of bulk cargo handling at river port using data envelopment analysis, (in Serbian), Tehnika -Saobraćaj, Vol. 57, No. 4, pp. $14-18,2010$

[18] Ramanathan, R.: An Introduction To Data Envelopment Analysis: A Tool For Performance Management, Sage Publications Pvt. Ltd, New Delhi, 2003

[19] Roll, Y. and Hayuth, Y.: Port performance comparison applying data envelopment analysis, Maritime Policy and Management, Vol. 20, No. 2, 1993, pp.153-161

[20] Subhash C. Ray: Data Envelopment Analysis: Theory and Techniques for Economics and Operations Research, Cambridge University Press, London, 2004
[21] Tongzon, J.: Efficiency measurement of selected Australian and other international ports using data envelopment analysis, Transportation Research Part A, Vol. 35, No. 2, 2001, pp 107-122

[22] Twrdy, E., Beškovnik, B.: Planning and decision-making to increase productivity on a maritime container terminal, Promet Traffic\&Transportation, Scientific Journal on Traffic and Transportation Research, 2008, Vol. 20, pp. 335-341

[23] Valentine, V.F., Gray, R.: The measurement of port efficiency using data envelopment analysis, in Proceedings of the 9th World Conference on Transport Research, Seoul, July 2001

[24] Wang, T-F., Song, D-W., Cullinane, K.: The Applicability of Data Envelopment Analysis to Efficiency Measurement of Container Ports, IAME Panama 2002 Conference Proceedings, Panama, November, 2002

[25] www.danubeports.info/

[26] www.danubecommission.org/index.php/fr_FR/publication

[27] www.stat.gov.rs(http://webrzs.stat.gov.rs/axd/Dokumenti/bilteni/SaobBil5152007.pdf), (http://webrzs. stat.gov.rs/axd/Dokumenti/bilteni/SaobBil5152008. pdf)

[28] Yen-Chun, J. W., Mark, G.: Container port efficiency in emerging and more advanced markets, Transportation Research Part E, Vol. 46, No. 6, 2010, pp. 1030-1042 